\title{
On Fields of Bones, Headsmen and Madonnas: The Symbols and Figures of Central Europe in the Past 25 Years of Jáchym Topol's Writing ${ }^{1}$
}

The term Central Europe in the very title of this article calls for a preliminary explanation. The definition ought to be a simple and unambiguous one, and it should correspond with the topographical space fictively featured in Topol's work. I believe that one of the simple and useful ways of defining Central Europe for this purpose is to derive its existence from the 1335 Visegrád alliance. The complex and often difficult history of the Visegrád area from 1335 up to 1991 confirmed the precognition of the medieval parties of the alliance. Throughout the centuries, mutual relationships have been dependent on the actions and gestures which promoted (or unfortunately opposed), mutual respect and shared values in the area. After 1991, some radical voices denounced the newly formed Visegrád alliance as "a posthumous child" of the former strong bonds between the dissent circles of the member countries. The aphorism about those bonds being swept away by the first wave of pragmatic capitalism (Dolejší) were precocious, but clearly, the term Central Europe required redefining, because

1 This study has resulted from the Academic Prize awarded to Pavel Janoušek by the Academy of Sciences of the Czech Republic and from long-term support for conceptual development of a research institution; registration number 68378068 .

This work required usage of Czech Literary Bibliography research infrastructure resources (http://clb.ucl.cas.cz). 
its character was rapidly changing. The authors of the monograph on Central Europe, $V$ kleštích déjin (2009) came with the following proposition: "If Central Europe is to be redeemed, it has to be translated into the cultural mode; because in this form it made its intellectual career." (Trávníček 300; translation mine) Some of the literary activities of writers in Central-European countries contribute to such a career in a substantial way. They translate the conflicting interpretations of Central-European-ness into literary images which have the capacity to facilitate a deeper, spiritual and imaginative understanding of the ontology of the area. The following study examines three such images related to the theme of Central Europe in works of Jáchym Topol.

\section{Forming a Perspective: Brief Biography of Jáchym Topol}

While in the case of some writers, the personal history of the writer and his or her work are relatively independent of each other, in the case of Jáchym Topol, the work and life are deeply correlated. In the early 1980s, Jáchym Topol ( $\left.{ }^{*} 1962\right)$ joined Prague underground circles, became active in the České děti (Czech Children) group. He started publishing in samizdat editions and magazines (Violit and from 1985 the review Revolver Revue, originally named Jednou nohou). For the members of Czech and Slovak underground, Poland and Hungary were substantial political and cultural partners: this was true especially about Poland, which was fascinating for the Czechoslovaks both due to its stout anti-communist resistance and due to the relatively low limitations on the cultural scene. Also, the cultural censorship in Hungary was much more liberal than the one in Czechoslovakia, and young intellectuals often travelled to Budapest in order to see films or to buy recordings of rock bands not available in their home country. The dissent and underground circles in the Central European countries were not only active in various ways of cultural exchange, ${ }^{2}$ but also put significant effort into activities leading to the reconstruction of twentieth century history of the region which the official communist and socialist interpretations tried to suppress and obliterate.

Part of the samizdat editions which Jáchym Topol and his circle co-produced in 1980s were thus memoirs and interviews dealing with the theme of the Holocaust in Europe (e.g. Marek Edelman's interview with Hanna Krall about

2 In 1986 Topol's political activity intensified; he signed Charter 77 and developed stronger contacts to the Polish underground, and he was caught smuggling printed material into Poland. Due to this activity, he was shortly imprisoned (per chance, amnesty celebrating 70 years of Czechoslovakia took place briefly afterwards). 
the Warsaw Ghetto uprising). Due to the anti-Semitic elements of the communist doctrine, the officials tried to suppress even such testimonies. Other themes which the members of dissent were trying to bring forth were the true picture of the political and military events of the Second World War and the history of resistance against the Nazi and Soviet political expansiveness. ${ }^{3}$

In 1990s, Jáchym Topol capitalised on his knowledge of these themes as a reportage journalist. Alongside his journalistic activities, he also became one of the most recognised Czech novelists as well as a cultural and political campaigner. Not only Topol's journalism, but also his prose and drama of the past 25 years are truly obsessed with the history and character of Central Europe. Of course, literary reflection of politics and history does not re-construct it, but by creating a fictional world ${ }^{4}$ it facilitates an intuitive, symbolic or even spiritual understanding of it and enhances the personal perspective. In the following part of the article, several of the symbolic keys employed in Topol's writing in relation to Central-European themes are examined.

\section{The Holocaust Arc in Topol's Novels and the Incorporation of the Theme of Soviet Gulags}

When rummaging through Topol's works written and published around the turn of the millennium, the sense of thematic continuity is really striking. Some of the themes, motifs and figures which reappear in Topol's writing relate to the sphere of the private (such as the absent, alcoholic mother and the crippled brother), some express the author's fascination with particular literary phenomena, such as myths of North American aborigines, the writings of Jaroslav Hašek, or the work of Czesław Miłosz.

In the meantime, a significant number of recurrent motifs and themes are related to Central-European history and to its present reality.

The matrix of those themes can actually be found already in Topol's first novel, Sestra (City Sister Silver) (1994). In retrospect, the work reflects the dismal atmosphere of the 1980 os in Prague, and then pictures an impressive, fantastic and frantic "outburst" of business, political, social and religious activities which followed the fall of the communist regime in 1989. The structure of the novel is extremely complex, and it was justly labelled "a puzzle, a kaleidoscope ... an

3 Events such as the defeat of the Warsaw Uprising in 1944, Budapest Uprising in 1956, Warsaw June in 1956 and Prague Spring in 1968.

4 To be more precise, in the case of Topol's literary appropriation of history, it is more accurate to introduce the term counterfactual historical fiction. (Doležel) 
encyclopaedia of post-communist life, written in a very unconventional epic manner" (Kaptayn 267). Within this kaleidoscopic structure, a surprisingly compatible and monothematic section appears, the 25-page-long chapter on Auschwitz (Topol 2000: 95).

Substantial attention has been paid to the chapter itself, to its dichotomic structure and intertextual bonds, and to the way it presents the theme of the Holocaust (Holý 2007; Holý 2011; Jürgensová, Marszałková; Ibler; Chew). In the following paragraphs, I would, however, like to prove that-on a particular level-the Auschwitz chapter is not related only to the catastrophe of the Holocaust, but to all of the (Central) European history.

The striking symbol employed throughout the "Auschwitz chapter," and recurring in later Topol's writing, is the symbol of the field or pile of bones. The protagonist of City Sister Silver and a group of his friends are transported to a vast field of bones covering the area of extermination camp and they willy-nilly take part in a tour guided by a skeleton. The image of the field of bones is intertextually bonded with the Old Testament book of prophet Ezekiel and his vision in chapter 37 . Here, the bones are later joined together, covered with meat and brought back to life. In City Sister Silver, the bones and skulls seem to be talking to the protagonist and his friends. As Jiř́ Holý underlines, the "hundreds of thousands of skulls on the field of death" shout at the protagonists purposely misquoting the text from Matthew 27, 25: "Our blood on you and your children!" (Holý 2011: 60). Holý interprets this part as underlining the co-responsibility of the Czechs for the genocide of Jews. It is possible to further this observation. Jewish victims in Topol's Auschwitz come "from Pest ... or from Košice," but the Nazi officers and their helpers come-ironically-from the same cities. The members of the group of friends who are (in a dream) taken on this tour through Auschwitz, represent the various strata of contemporary European society as well as its religions, Judaism and Christianity, and none of them, significantly, are able to walk on the bones. All are drowning in the bones. Thus, the novel indicates that both the open collaboration and the structural, "blind" collaboration with the Nazi extermination of the Jews is the problem of all of (Central) Europe, including even some of the members of the Jewish community itself.

The field of bones image returns yet in another dream in City Sister Silver. This time it is related to the character of the French symbolist poet Rimbaud, in the novel misspelled as Rimbow. In a dream, Rimbow escapes Europe so as to "walk on the firm rock" and to get a chance of writing. He escapes not only because of his dread of superficial life (he wants to "turn his back to the carnival"), but because of his desire to write: his deepest reason is the fact 
that "Earth hurt his feet.... Sharp bones jutted out all over the Earth, lacerating him... Deserting to Ceylon, he made his way through the rain forests and up to the mountains so he could get firm rock underfoot instead of a mass grave" (Topol 2000: 213). In this single image, Europe is presented as a society walking on the past graves, on former military attacks, murders and individual crimes. The symbol of the sharp bones relates fictionally to the previous centuries of European history and presents the Holocaust as its tragic culmination. In the fictional realm of Topol's work, it is clearly implied that the will to exterminate certain religious groups, political communities or even nations is deeply set in the genetic code of Europe and that it still lingers in present-day Europe.

\section{Mass Graves as a Thematic Arc in Topol's Novels and Dramas}

In a 2013 interview with Alex Zucker in The Quarterly Conversation (Zucker), Topol suggests that the theme of mass graves actually forms a thematic "arc" in his writing. He speaks about his "journey around the scars of Central or Eastern Europe," about "dozens, hundreds of trips around the ruins of Soviet empire, with prolonged stays in Slovakia, Poland, and Ukraine, a fifteen-year journey that led ..., ultimately, to the graves of Belarus." This "arc" begins in City Sister Silver, and finishes in Chladnou zemí (The Devil's Workshop) (2009).

The image of walking on or amongst piles or fields of bones returns again in Topol's post-apocalyptic drama Cesta do Bugulmy (2006) (Journey to Bugul$m a) .^{5}$ In it, Europe is devastated by the Third World War. Its last inhabitants flee to the Soviet town of Bugulma hoping to find a rescue there. The only witness of Bugulma's past is "comrade Jerochymová" (the name alluding to "Comrade Jerochymov” in Hašek's renowned prose Velitelem města Bugulmy (Commanding officer, Town of Bugulma) (1921), and she finally reveals the real purpose this (fictitious) Soviet working camp has had. The formerly arctic conditions are changing, snow is melting and what previously seemed to be hills and mountains covered by snow, gradually turn out to be hills and hills of frozen dead bodies of Soviet prisoners. The present refugees were-unknowingly-walking on them.

The image of the piles of bones returns again in the fictional world of the "Theresien-Khatyn" novel Chladnou zemí (The Devil's Workshop) (2009). The novel often refers to historical events, but merges these references with contra-factual narration. In the opening, the novel depicts the moment when Terezín concentration camp is being freed from the Nazis at the end of World War II. The I-narrator's father serves as a drummer and while his troop is freeing

5 The the text has not been translated into English so far. 
Terezín, he finds a young girl still alive in a pile of corpses. The naked Jewess rising from a pile of corpses may be seen as a symbol of the partial resurrection of European Jews after the war.

In parallel to the actual history of the fortress town of Terezín (which began to disintegrate after the departure of soldiers in the 1990s), the now adult I-narrator and his uncle Lebo are portrayed trying to preserve the Terezín ghetto by starting a commune. In the counter-factual narration about the commune, the novel portrays particular types of people attracted by former ghettos and mass graves. The narrator's lover in the commune, Sára, is one of those "bunk seekers," those European (or American) young who go "digging through the damp ruins of Poland, Lithuania, Russia-in short, everywhere mass graves were common" (Topol 2013: 32) and who are actually trying to deal in this way with their own hurt or loss of direction. Sára and the I-narrator narrowly escape a modern "pogrom" in Prague, led by an armed group of youth and clearly supported by the present-day inhabitants of the city (this pogrom being primarily directed against the Romas, but it is obvious that Jews and other groups are also potentiality in danger).

Soon after this incident, the novel, in its wild narrative manner, shifts to the Belarusian sites of mass killings, to Minsk and later to Khatyn or Chatyń. ${ }^{6}$ Especially here, the image of piles of bones is semantically furthered. The bones dug out by a sectarian group in Minsk represent the individual "layers of crimes" of the twentieth century in Central and Eastern Europe. The impression of universal culpability and general onus is immensely strong in those passages. This applies even more in the retrospective narration about Oktyabrsk. In it, German scientists, despite all the scientific methods available to them, remain clueless as to the identity of hundreds and hundreds of dead bodies found in the mass graves they examine.

Was it Soviets killing Soviets, or Germans murdering Soviets and Jews, or Germans and Soviets killing other Soviets? Then on top of that, consider that here they were divided into Belarusians and Russians

6 Belarusian Khatyn near Minsk was a one of the hundreds of Belarusian villages which were burned to the ground, including all of their inhabitants. The perpetrators here were the soldiers of the Schutzmannschaft Battalion 118, a battalion formed in 1942 in Kiev, mostly of Soviet prisoner-of-war volunteers, Ukrainian collaborators and deserters. (Not to be mistaken with the Katyn near Smolensk and the Katyn Forrest massacre which took place in 1940; here, thousands of Polish officers were murdered by the Soviet secret police, the NKVD.) 
and Ukrainians and Ruthenians, and then of course there were also Poles and Balts ... (Topol 2013: 154).

Both in the fictional Terezín and in Minsk and Khatyn, the attempts to dig up-literally and metaphorically_the bones, and to preserve them, are portrayed not only as an appropriate search for the historical truth about Central and Eastern Europe, but also as an activity which can be abused in many ways. Ironically, both the Belarusian president (a dictator) and his political antagonists are supporting the creation of a new museum of mass graves, both seeking the propagandist potential of such findings. ${ }^{7}$ The Belarusian commune gathered around the museum named "the Devil's Workshop" in Khatyn are socially and morally perverted people, and the narration gradually turns into a horror story. While the fictional pogrom in present-day Prague presents a relatively minor event, in Minsk, the I-narrator witnesses a police-provoked anti-Semitic riot which resembles the prelude to the Kristallnacht in November 1938. The terrible experiences of the past decades (and centuries) were not enough, the threat of aggression is present in present-day society. In the closing of the novel, a German scientist sums up: "the time to uncover the fields of bones still has not come yet. 'And you know why? Because the devil's still active as hell here!'” (Topol 2013: 157).

\section{The Good-Hearted Headmen: Topol's Typical Czechs}

While the symbol of the fields of bones represents both the history of crimes committed in Europe and the present-day attitudes which might lead to their repetition, the Auschwitz chapter in City Sister Silver introduces yet another figure developed in Topol's later works and related to the treatment of Central European themes as such.

It is a particular character which-in allusion to the renown literary character authored by Jaroslav Hašek — may be named "the good headsman." Hašek's iconic "good soldier" Josef Švejk is often perceived as a typical Czech under the Habsburg monarchy: meticulously obedient and seemingly naïve, lacking ambitions, capable of ignoring the cruelty of war and subverting many situations against his superiors, he represents the stereotypes of Czechness.

7 "The president has an interest in utilizing the burial sites and developing tourism, as do the opposition leaders... Khatyn will be home to the Devil's Workshop, a museum for Europe, for the world." (Topol 2013: 114) 
In City Sister Silver, Topol introduces a character in many aspects resembling Josef Švejk, but situated further on into the fictionalised twentieth century. It is his "Josef Novák from Žižkov." While Josef Švejk willingly enters the service in the Austrian army, Josef Novák decides to pretend to be a Jew and ends up in Auschwitz. In parallel to Švejk’s faithful service to Lieutenant Lukáš, Novák faithfully serves the pervert Nazi torturer, Oberst Prochaska, becoming thus a "good headsman." Ironically, the narration indicates again and again that he is a typical Czech. ${ }^{8}$ It is not just due to his speaking name (equivalent to John Doe in English), but also due to his patriotic love for the "little mother" (matička, the city of Prague) and his die-hard conviction that Czechs always get along with each other. Alongside those qualities, Josef Novák displays an amazing capacity to demean himself for the sake of survival, ${ }^{9}$ and to kowtow to the Nazis. He is happy with his superior and good-heartedly speaks of assisting his atrocities $\ldots$ he even admits taking part in the torment of children. ${ }^{10}$ On one occasion, however, the appalling good-heartedness takes on the likeness of mercy, overcoming the New Testament parable of the Lazarus and the rich man (Luke 16, 19-31). After death, Novák visits Oberst Prochaska in hell. Unlike Lazarus who would not go and give water to the rich man in hell, Novák does go and does give drink of water to "that ole swine Oberst a mine."

In the mixture of mercy and cruelty displayed in this scene one may find the prelude to some of the scenes from Topol's "loveless" drama, published ten years after Sestra. The text of Uvareno (Cooked and Ready) was published in the Czech literary magazine $A_{2}$ in 2005, and has not been translated into English yet. The protagonists of the drama are three murderers, Soňa (Sonia, Czech feminine given name), Starík (Old Man) and Omyl (Mistake), all of them incarcerated in prison and pondering their previous lives.

Stařík is a completely numb man; he only feels pity when remembering his childhood in the Soviet concentration camp in Perm, where he eventually learnt the "art of hanging." After this, wwII took Stařik eastwards (perhaps suggesting

8 The fact that this "anti-hero," is a typical representative of Czech nation is underlined also by references to other Czech prisoners and their capacity to "adapt to" the horrific situations in concentration camp. Novák recounts for example the collaboration of the famous Czech writer Karel Poláček with the prison system in Theresienstadt.

9 "An so I raise my right hand an go: Heil Hitler, meine offizieren und docktoren an scholars. Ich bin eine kleine tschechische schweine, geboren aus Žižkov, howdy do, Novák from Prague here. Greetins, everyone, and long live the Führer and the Thousand-Year Reich! Hip hip hooray!” (Topol 2000: 103).

10 The description of Novák's treatment of the children ("nippers") in "Prochaska's kindergarten" (Topol 2000: 112-113). 
that he was one of the "sons of the regiment"), to Prague. In Prague, Staŕík worked as a headsman under all of the regimes which ruled the country. After Havel abolished capital punishment, Stařík lost his job. Jobless and frustrated, one day he exterminated all of the people in gardeners' colony in Podbaba. In his monologue, Stař́k feels no remorse for this event, but he keeps returning to "Mrs. Milada," ${ }_{11}$ a convict he had executed. The figure of this old man headsman in Cooked and Ready resembles in many ways the character of Josef Novák in Sestra. Executing or killing other people becomes a matter-of-fact issue for him; he is sentimental only when remembering his childhood. While Novák dies some time before the end of WwII in Auschwitz, Stařík's life of a good headsman "represents" the story of the Czech nation under the political establishments of the second half of the twentieth century. Stařík recalls executing members of Vlasov's Russian Liberation Army, executing the Germans, executing the Czech collaborators of Nazis, and executing the "civilians" sentenced to death under Czechoslovak socialist regime. Similarly to Josef Novák, he is incapable of discerning the difference between the political and human context of those various deaths. To him, there are no victims and no heroes, with one exception: Mrs. Milada (allusion to the famous Czech victim of communism, Milada Horáková). In Stařík's perception, she was a heroine, not humbled by death, not afraid of it. The mad headsman wants to follow her example, and ironically does so by committing suicide in the prison.

In 2007, the Torst publishing house issued a collection of Topol's shorter prose and theatre texts named Supermarket sovětských hrdinư. ${ }^{12}$ Besides the re-publication of Cooked and Ready, the book contained also a new drama, Journey to Bugulma. The character of a good-hearted headsman is present in this dramatic text, too. The "journey to Bugulma" is a journey of a family of three Czech headsmen (grandfather, father, and son), who want to reunite with the mother sent to Bugulma with a specialised NATO troop. The grandfather dies, but the father and the young son of the family, Jeník, do reach Bugulma. In retrospect, the drama recounts the story of the family. The father lost his job as a headsman under Havel and he takes a forced parental leave with his son, caring for him with surprising tenderness. Presently, the only thing the father

11 Historically, Dr. Milada Horáková was a lawyer, a member of anti-Nazis resistance, and later one of the most renowned Czech opponents of communism, a strong believer, mother to a teenage daughter. She was executed in a fabricated process in 1950 at the age of 48 years.

12 The collection was published in Polish prior to the first Czech publication (Topol, Jáchym. Supermarket bohaterów radzieckich. Wołowiec: Czarne 2005). 
is afraid of is the emasculation brought by democracy, tolerance, free market and by the loss of tradition and values in the EU. He desires his son to become a warrior, a fighter against the unidentified terrorists who started the Third World War. The son, an urban type of a young man addicted to drugs, is however obviously incapable of such heroism.

In Topol's next novel, The Devil's Workshop (2009), presented in this article in relation to the symbolic fields of bones, the figure of a good-hearted, or polite headsman also plays two minor roles. The I-narrator of the novel is imprisoned for more or less accidentally killing his father. In prison, he comes to know a sensitive, well-educated headsman, Mr. Mára. Mr. Mára was incarcerated after a fabricated process with "cyberneticists, traitors of the people," though he was innocent. The prison administration, however, recognized his skills and he ended up as the executioner. In his own words, even in prison, "socialist cybernetics remained his passion" (Topol 2013: 12). Mr. Mára chooses the I-narrator to be his assistant: the I-narrator is preparing the convicts for executions and walks them down to the execution chamber. He has an outstanding capacity to calm the convicts down and to help them accept their fate, thus becoming a good-hearted headsman himself. After the fall of communism, Mr. Mára moves to the United States of America and earns a fortune for a computer game which he programmed while in prison. The breed of the good-hearted headsmen, these "typical Czechs" of Topol's works, enters the new millennium here, and-ironically-their fate now follows the American dream. The ironic image of a cyberneticist socialist headsman who later successfully works in the us is underscored by the reference to Wernher von Braun (Topol 2013: 131) in the book. It is not just "the typical Czechs" who are thus identified as being turncoats.

\section{The Images of Madonna in Topol's Fictional Worlds}

The strategies of fictionalising Central Europe in Topol's works could be illustrated by a set of other character types, for example the "son of the regiment" type, "false relative" or "false Russian relative" type, "the tankist" and many others. All of these, however, belong to the same fictional realm as the character of the good-hearted headsman.

There is, nevertheless, one more level on which the search for symbols and figures of Central Europe in Jáchym Topol's writing can be carried out. It is the level which Jan Assmann denotes as "Gegenwelten."

In his study on the counterworlds in the Greek and Roman cultures "Gegenwelten zu den Kulturen Griechenlands und Roms in der Antike" (2000), Assmann argues that human beings lead a triple life: one taking place in their 
physical environment, "Umwelt," one in the comprehensible world, "Welt" and one related to a counterworld, "Gegenwelt." Assmann claims that counterworlds, composed with regard to the concept of the "other side" (Jenseit), communicate various "pictures of the ideal" (Feinbildern) and therefore relate to the questions of purpose and meaning in life and death. Counterworlds are therefore chief sources of human identity, and-as Assmann shows-literature participates in their transmission.

The search for depictions of counterworlds in Topol's writing should, once again, start with his novelistic debut, City Sister Silver. Here, the quest for "the sister" is not aimed at finding just a lover or soul-mate. This quest incorporates the transcendental dimension, too. The sisters from a religious order, though possibly just delusions of ill Jícha, represent this dimension. Moreover, "the sister" who the narrator looks for definitely alludes to the Black Madonna. Though the character of the Black Madonna is at moments open to ambivalence, its prevalent meaning is related to the counterworld of Christianity. While the novel is chiefly set in fictional Prague, the Black Madonna is not the Prague Black Madonna. As Leszek Engelking shows in his study "V mládí jsem občas chtěl být Polák...," the metal image of patron saint which Jícha touches on his breast, is the image of the Black Madonna of Częstochowa. ${ }^{13}$ It is out of the metallic image of this Black Madonna that Jícha makes a bullet with which he (possibly) shoots the Devil in the novel. While the Black Madonna in City Sister Silver grants protection, God is depicted as "the Face" and his message to the protagonist is the appalling vision of Messiah killed among the Jewish children in Auschwitz. The death of the child means loss of salvation for humankind and also the death of time, and God/the Face immerses in deep silence.

In the following novel, Anděl (Angel Station) (1995), set again in fictional Prague, the character of the counterworld is derived from the triangle of women who symbolically represent three cardinal virtues of Christianity (VerraFaith, Nad'a-Hope, and Ljuba-Love). The fates and characters of the ladies in the novel are to a degree contradicting their Christian names. The brave, loving and understanding Ljuba (Love) may be seen as a representation or incarnation of a Czech Madonna. She is almost a martyr of femininity, she loses her child, and almost dies in maternity hospital. A typical Czech Madonna of the 1990s, she is a Madonna stripped of the traditional faith.

The image of Madonna in European culture is usually the image of a guardian or of patron saint to the individual nations and cities. In the novel Kloktat

13 Possible reference to the uniform of Polish officers who wore the plaquete with the Black Madonna. 
dehet (Gargling with Tar) (2005), such an image is distantly evoked in the picture of Čechie, a legendary patroness of Bohemia, a fraud character made-up by Czech writers of the nineteenth century. Čechie is not a historical figure or historical saint, and Czechs in the novel, therefore, seem to be uneducated people who follow a cluster of fraud stories rather than a substantial creed.

After the completion of the "Holocaust arc," Topol sets up a cluster of new motifs and images in his long-awaited novel Citlivý člověk (2017). ${ }^{14}$ Here, contemporary Bohemia and Europe are once again reflected fictionally, this time from a beat and bastardized, yet visionary, point of view.

The burlesque, unpolished novel depicts, among other significant themes (such as the danger of Russian political interference), the potential abuse of (Christian, or any other) faith. In the opening part of the novel, the narrator visits a sectarian monastery in fictional Ajvaristan. He is told that it is the monastery of "Madonna of War, mother of the native country" (Topol 2017: 60) and that alongside with the countrymen, the monks here formed a (fictional) Russian Orthodox Army. The abuse of religious symbols and feelings which occurred so many times in European history is represented by the terrible oxymoronic image of "Madonna of War."

While in the first part of Citlivý člověk, it is this horrific Madonna of War who protects the Russian Orthodox monastery, in the second part of the novel (taking part in the surroundings of Czech river Sázava), a new image of Madonna is introduced, the image of Czech Madonna of Pořićí. Her picture has-tellingly_long been lost, but the river brought it to a fisherman. It is a (fictional) Madonna of a small town, guardian of the bastardized Czechs living on the outskirts of the European and Czech society. Her picture escapes not only water but also fire in the fisherman's hut, and eventually saves the fisherman's life. The introduction of this "active" and "protective" Czech Madonna into the fictional Bohemia is symptomatic of the new dimension which the fictional world in the novel accommodates. Alongside the presence of this miraculous picture, it is also the pregnancy and maternity of some of the key female characters in the closing scene that signals a turn in the symbolic depiction of present-day Bohemia and Central Europe. Even though the Czechs in it are a nation of outcasts, prostitutes, alcoholics, frauds and homeless, the atmosphere of the novel is no more a doomed one. The counterworld of Christian faith has once again been conquered and made their own. The long-lost Czech Madonna creates a connection to the positive aspects of European history

14 At the moment of writing this study, Alex Zucker was preparing the English translation of Citlivý člověk for the Yale University Press tentatively titled A Sensitive Person. 
and brings - as a guardian to the primitive village people-glimpse of hope to the present and the future.

\section{Conclusion}

The three symbols or figures of Jáchym Topol's chosen for closer observation in this paper relate to Central European history, to its human character and to its spiritual code or, in Jan Assmann's words, to its counterworld dimension. The image of the field of bones is related to the catastrophe of Holocaust and beyond it to all of the layers of crimes in (Central) European history, but also to the present European situation and the dangers hidden in it.

The figure of a good-hearted headsman embodies the ambivalent character which both Czechs and other Central European nations displayed under historical pressure. It is not a flattering image. By employing it, Topol tries to confront the tragic failures and weaknesses of human character in an artistic manner. The drastic humour and the hyperbolic depiction related to this character nevertheless also indicate that the often-repeated phrase about the Švejkian character of our nation is no longer plausible. In the context of the twentieth century history, the good soldier would have to become a good headsman. Eventually, Josef Novák needs to be redeemed from his unacceptable position, and Topol's novels and dramas present an artistic search for such redemption.

As shown in the third part of the study, the counterworld dimensions of Topol's works which are related to feminine sensitivity and to feminine aspects of the spiritual seem to offer such redemption. The line of various Madonnas in Topol's novels depict the gradual development towards a new and deeper acceptance of spiritual, fruitful and positive aspects of European history.

\section{| References:}

Assmann, Jan. “Ägypten als Gegenwelt.” Gegenwelten zu den Kulturen Griechenlands und Roms in der Antike. Ed. Tonio Hölscher. München: Degruyter, 2000. 67-83.

Chew, Geofrey. “'Dissidence’ in Holocaust Memorials in Literature: Jáchym Topol's Devil's Workshop (Chladnou zemí)." Central Europe 15 (2015), https://tinyurl.com/yagpahyh. Accessed 12 April 2015.

Dolejší, Karel. "Milan Kundera a tragédie střední Evropy." Britské listy, 15 October 2006, https://legacy.blisty.cz/art/43224.html. Accessed 12 December 2019. 
Doležel, Lubomír. Heterocosmica II: Fikční světy postmoderní české prózy. Praha: Univerzita Karlova v Praze, 2014.

Engelking, Leszek. "V mládí jsem občas chtěl být Polák... .Polsko, polština a Poláci v románu Sestra Jáchyma Topola." Otevřený rány: vybrané studie o díle Jáchyma Topola. Ed. Ivo Ríha. Praha: Torst, 2013. 77-88.

Hašek, Jaroslav. Velitelem města Bugulmy. Praha: Československý spisovatel, 1966.

---. "Commanding Officer, Town of Bugulma." Behind the Lines. Bugulma and other stories. Trans. Mark Corner. Praha: Karolinum, 2012. 7-21.

Holý, Jiří, et al. Holocaust-Šoa-Zagłada v české, slovenské a polské literatuře. Praha: Karolinum, 2007.

---, ed. Šoa v české literatuře a kulturní paměti. Praha: Akropolis 2011.

Jürgensová, Zuzana and Marszałková, Magdalena. "Svědci a dědicové dějin: holokaust v české literatuře." Otevřený rány. Vybrané studie o díle Jáchyma Topola. Ed. Ivo Ríha, Praha: Torst, 2013. 263-275.

Kaptayn, Valentina. “Another Way to Remember. Jáchym Topol’s Works Sestra (1994) and Chladnou zemí (2009) in the Context of Czech Cultural Memory of the Holocaust." The Holocaust in Central European Literatures and Cultures since 1989. Ed. Reinhard Ibler. Sttugart: Ibidem-Verlag, 2014. 263-274.

Topol, Jáchym. Sestra. Brno: Atlantis, 1994.

---. Anděl. Praha: Hynek, 1995.

---. City Sister Silver. Trans. Alex Zucker. North Haven: Catbird Press, 2000.

---. "Uvařeno." A2 2 (2005): 1, 25-26, https://tinyurl.com/y784hq8q. Accessed 12 April 2015.

---. Kloktat dehet. Praha: Torst, 2005.

---. Supermarket sovětských hrdinů. Praha: Torst, 2007.

---. Gargling With Tar. Trans. David Short. London: Portobello, 2010.

---. The Devil's Workshop. Trans. Alex Zucker. London: Portobello, 2013.

---. Angel Station. Trans. Alex Zucker. Victoria, Tx: Dalkey Archive Press, $2017 \mathrm{a}$.

---. Citlivý člověk. Praha: Torst, 2017b.

Trávníček, Jiří, ed. V kleštích dějin. Střední Evropa jako pojem a problém. Brno: Host, 2009.

Zucker, Alex. “The Jáchym Topol Interview." The Quarterly Conversation 33 (2013). 2 September 2013, https://tinyurl.com/kwtcutw. Accessed 12 April 2020. 


\section{| Abstrakt}

KláRA Kudlová

Kości, kaci i madonny. Symbole i figury Europy Środkowej w twórczości Jáchyma Topola ostatnich 25 lat

Na czeskiej scenie literackiej Jáchym Topol uchodzi za autora najbardziej zainteresowanego Europą Środkową, nieustannie rozszyfrowującego przekaz zapisany w jej bliznach i zmarszczkach. Jego stosunek do tematów środkowoeuropejskich w tekstach fikcyjnych jest zawsze oparty na pogłębionym zapoznaniu się z historią i współczesnością tego obszaru. Topol nie jest jednak historykiem: tworząc fikcję, wykorzystuje złożoną, poetycką perspektywę i osiąga autorski typ ekspresji artystycznej. Określone, powracające symbole i figury zdają się w zagadkowy sposób odpowiadać na współczesne pytania Europy Środkowej. Pierwszy z tych symboli to biblijny obraz doliny suchych kości. Reprezentuje on zarówno metodyczną przemoc w historii środkowoeuropejskiej, jak i uniwersalną odpowiedzialność. Drugi to typ postaci występującej w wielu utworach Topola: dobry kat. Uosabia on ambiwalencję czeskiego charakteru narodowego, ale również jego strategię przetrwania. Postać dobrego kata intertekstualnie łączy się z twórczością Jaroslava Haška - przyjęte powszechnie przekonanie, że „Czesi są narodem Szwejków”, zostaje doprowadzone do absurdu. Trzecim symbolem pojawiającym się w twórczości Topola jest postać Madonny, reprezentującej duchowy wymiar środkowoeuropejskiej tradycji związanej z chrześcijaństwem. Madonny - polska Matka Boska Częstochowska, wojenna Madonna w fikcyjnej współczesnej Rosji, czeska Madonna z Poříčí - tworzą chrześcijańskie „przeciw-światy”. Madonny sygnalizują niezastąpioną rolę duchowości w Europie Środkowej, jej rozwój i stałą obecność. W ostatniej powieści Topola, Citlivý člověk (wyd. polskie Wrażliwy człowiek, 2019), dzięki postaci Madonny dyskurs uzyskuje nową perspektywę.

Słowa kluczowe: Jáchym Topol (1962); Europa Środkowa w literaturze; Visegrád; Sestra (1994); dolina suchych kości; Holokaust w literaturze; Chladnou zemí (2009); Cesta do Bugulmy (2006); Velitelem města Bugulmy (1921); Uvařeno (2005); postać dobrego kata; Jaroslav Hašek; Jan Assmann; Gegenwelt; Madonna w literaturze; kulturowy wymiar; duchowy wymiar 


\section{| Abstract}

\section{KLÁRA KudLOVÁ}

On Fields of Bones, Headsmen and Madonnas: The Symbols and Figures of Central Europe in the Past 25 Years of Jáchym Topol's Writing

In the Czech literary scene, it is Jáchym Topol who may justly be labelled the author most consumed with Central Europe, one who is constantly attempting to decrypt the message encoded in its scars and wrinkles. His fictional treatment of Central-European themes is preceded by thorough knowledge of both the history and present state of the region. However, Topol is not merely a historian; in his fictionalising he uses a poetic, complex perspective, and arrives thus at a unique expression. Particular recurring figures in his literary work seem to answer in a riddle the questions of present-day Central Europe. First one of those is the biblical image of the field or of the pile of bones. In Topol's writing, it represents both the systematic violence in Central-European history, and universal onus. The second recurring figure is the figure of a good-hearted headsman. In Topol's prosaic and dramatic texts, the headsman embodies the ambivalence of the Czech national character, but also its survival strategies. It is intertextually linked to the works of Jaroslav Hašek, and brings the notion "Czechs are a Švejk-like nation" to its absurd, augmented consequences. The third figure which keeps returning in Topol's work combines the features of a character and of a symbol. It is the figure of Madonna, representing the spiritual dimension of Central European tradition, bound to Christianity. The various Madonnas - the Polish Madonna of Częstochowa, the War Madonna in fictionalised modern-day Russia and eventually the Czech Madonna of Poříćí create the Christian counterworld in Topol's novels, and signalize the persistent role and presence of spirituality in the region. In Topol's novel Citlivý člověk it is actually thanks to this Madonna that the whole discourse opens to a new type of perspective.

Keywords: Jáchym Topol (1962); Central Europe in literature; Visegrád; City Sister Silver (2000); the field of bones; the Holocaust in literature; The Devil's Workshop (2013); Cesta do Bugulmy (2006); the figure of good headsman; Jaroslav Hašek; Commanding officer; Town of Bugulma (2012); Uvařeno (2005); Jan Assmann; Gegenwelt; Madonna in literature; cultural mode; spiritual mode 


\section{| About the Author}

Klára Kudlová is a Czech literary historian. She studied English, American and Czech philology at the Philosophical Faculty of Charles University in Prague (Ph.D. 2011). She presently works as a post-doctoral researcher in the Department for Research into 2oth Century and Contemporary Literature of the Czech Academy of Sciences and lectures on modern literature at the Catholic Theological Faculty of Charles University.

E-mail: kudlova@ucl.cas.cz 
